Т. І. Веретільник, к.т.н., професор, e-mail: vertim@mail.ua, Л. Д. Мисник, к.т.н., доцент, e-mail: l.mysnyk@chdtu.edu.ua, О. В. Манзюра, ст. викладач, e-mail: fktm-email@ukr.net, Р. Б. Капітан, $c m$. викладач, e-mail: kapitan_ruslan@ukr.net

Черкаський державний технологічний університет б-р Шевченка, 460, м. Черкаси, 18006, Україна

\title{
ЗАСТОСУВАННЯ КОЛІРНИХ ГАРМОНІЙ ТА ВІДТВОРЕННЯ КОЛЬОРУ В ПОЛІГРАФІЇ
}

У статті розглянуто деякі аспекти колірної гармонії та кольороутворення в поліграфії, використання природної гармонійності кольорів у художньому проектуванні об 'єктів поліграфічного та мультимедійного виробництва.

Ключові слова: колір, гармонія, колірне сполучення, гармонія кольору, колірна композиція, кольороутворення.

Постановка проблеми. Все, що оточує нас, має певний колір, в природі немає безбарвних предметів. Одні кольори дуже яскраві і чисті, інші - бліді і настільки невизначені, що їм важко підібрати назву. Безмежна зміна колірних вражень супроводжує нас все життя. Більшу частину знань про оточуючий світ отримуємо, сприймаючи візуально колір, котрий ще з древності був і засобом інформації, i символом, і окрасою. В цьому полягає його соціальне значення. Вивчення кольору, як константи естетичного сприйняття, є важливою потребою часу.

Особливо актуальним $є$ дослідження кольору в поліграфії. Основна задача, яку вирішують поліграфічні технології - це високоякісний друк кольорових зображень максимально наближених по відтворенню кольору до оригіналу. Досконалості немає меж, особливо коли мова йде про предмет, пов'язаний зі сприйняттям кольору. В умовах інтенсифікації розвитку процесів поліграфічного та мультимедійного виробництва гостро постає питання створення таких колірних рішень продукції (етикеток, обкладинок книг і журналів, зображень на їх сторінках, елементів керування та навігації у мультимедійних виданнях навчального, дидактичного, розважального спрямувань тощо), що дозволить не лише привернути увагу споживачів, але й вплинути на їх рішення про придбання даної продукції. Однак для формування грамотного та доцільного колірного рішення продукції необхідно використовувати спеціалізовані знання щодо формування гармонійних колірних сполучень, формування колірних профілів, використання технологій кольороподілу, кольоровідтворення та ін.

Аналіз останніх досліджень і публікацій. Проблеми кольору в мистецтві, архітектурі досліджувалися багатьма вченими та художниками 3 давніх часів. У кожну історичну епоху створювалися свої уявлення про колірну гармонію, розроблялися гармонійні колірні схеми, що активно використовувалися в художній практиці й істотно відрізнялися одна від одної за характером підбору і сполучення кольорів.

Науці про колір, зокрема питанням побудови колірних гармонійних сполучень, присвячені праці відомих вчених: Й. Гете, В. Освальда, Ж. Агостона, Р. Івенса, Р. Іттена, М. Коула, М. М. Волкова, Л.Н.Миронової, О. С. Зайцева, В. Ф. Ковальова, В. Н. Козлова, М. М. Степанова, Г. Цойгнера, П. Е. Шпари та інших.

Серед сучасних видань, присвячених як практичним, так і теоретичним питанням кольору і кольороутворення, чимало доробок вітчизняних та зарубіжних авторів, хоча переважно це посібники для широкого кола користувачів, тож основні моменти кольорознавства, як і проблема створення гармонійних 
колірних сполучень, авторами висвітлюються недостатньо.

У посібнику В. Ф. Рунге “Основи теорії та методології дизайну” [1] питання колірної гармонії подається здебільшого 3 позицій психологічного сприйняття споживачами, лишаючи поза увагою актуальність на сучасному етапі графічного комп'ютерного проектування. Серед сучасних вітчизняних дослідників грунтовно розглядає питання використання кольору, колірних асоціацій та поняття колірної гармонії в галузі художнього проектування С. В. Прищенко [2, 3]. У галузі технічної естетики деякі науковці, зокрема, I. О. Кузнєцова [4], займаються розробкою таких нових і цікавих напрямків, як візуальне сприйняття об'єктів мистецтва i дизайну на основі співвідношення світлих і темних елементів. Проблемам колірної гармонії у галузі художнього проектування приділяє значну увагу і відомий болгарський рекламіст Х. Кафтанджієв [5]. Р. Олтман [6] та Д. О’Квін [7] головну увагу приділяють чисто технічним питанням, важливим для видавничої поліграфiï, у скороченому форматі подають дані 3 фізичної природи кольору, а також питання утворення колірних каналів і двох основних колірних моделей CMYK та RGB.

Отже, як бачимо, у світовій та вітчизняній літературі колір і колірна гармонія вивчаються 3 різних аспектів, але висвітлення проблеми створення колірної гармонії у візуальних комунікаціях має доволі фрагментарний характер, колірна гармонія не розглядається як єдина комплексна система, а в останнє десятиріччя 3'явилася нова проблема гармонійного кольороутворення прикладного характеру 3 урахуванням комп'ютерних технологій виробництва, що визначає актуальність більш поглибленого вивчення даного питання.

Мета статті. Дослідження закономірностей побудови колірних гармонійних сполучень, використання природної гармонійності кольорів у художньому проектуванні об'єктів поліграфічного i мультимедійного виробництва та впливу кольору в сучасній поліграфічно-видавничій діяльності. Висвітлення деяких аспектів функції кольору та виникнення колірних асоціацій 3 позицій гармонійного кольороутворення.

Основний матеріал досліджень. У сучасних дослідженнях основними аспектами кольору обрано фізичний, символічний, психофізіологічний та образно-психологічний, проте вони не передбачають комплексний підхід до кольору як до одного 3 найважливіших художніх засобів у створенні візуального оточення.

Важливо зазначити що колір у поліграфічному дизайні дозволяє реалізувати його комунікативну функцію, адже, приміром, фірмовий колір має особливе значення для "впізнавання" фірми - поряд із фірмовими знаком і шрифтом. Ця функція базується на особливості кольору сприйматися й запам'ятовуватися значно швидше за письмову інформацію, і тому колір усе частіше стає одним із вагомих чинників створення стилю промислової продукції [8]. Професійне кольоро-графічне вирішення стає одним з основних важелів психологічного впливу на споживача, що звернений, в першу чергу, до емоцій людини. Кольорове рішення друкованої продукції не може бути випадковим. Точний і вірний вибір кольору для поліграфії залежить від трьох факторів: психології кольору, особливостей кольорового сприйняття i традиції нації по відношенню до кольору.

Грамотне використання кольору в поліграфії може виконувати ряд функцій: привертати увагу, покращувати запам'ятовування реклами, формувати позитивне відношення до товарів чи послуг, виокремлювати, підкреслювати окремі елементи, врівноважувати композицію. Повнокольоровий друк приваблює споживачів і запам'ятовується на 50-80\% більше, ніж чорно-білий.

Як і в живописі, колір у поліграфічній композиції - основа художньої мови, найбільш важливий формотворчий чинник, що впливає на почуття, створює настрій і є найважливішим засобом образно-психологічної характеристики зображення. Невипадково останнім часом зусилля поліграфістів і дизайнерів спрямовані на створення “емоційних" товарів і послуг.

Розробляючи поліграфічну продукцію, важливо не тільки використовувати засоби проектно-графічного моделювання шрифтів, знаків та символів, а також обгрунтовувати варіанти кольорографічних рішень для певних об'єктів-носіїв. Потрібно враховувати характер діяльності, необхідність забезпечення індивідуальності зображення, зрозумілість графічної мови та ін. Створюючи, наприклад, товарний знак, емблему чи логотип, необхідно паралельно розробляти виразні, композиційно завершені кольорові зображення як 
складові візуального повідомлення - кольорографічного тексту.

При роботі 3 кольором потрібно знати основні властивості кольорів і розуміти основні терміни кольорознавства: основний (первинний) колір, похідний (вторинний, третинний) колір, тональність, відтінок. Необхідно уявити бажаний результат, який досягається за допомогою кольору, потім зорієнтуватись у виборі основного кольору, що задовольняв би потреби проекту, далі потрібно вибрати комбінацію залежні від обраної гами і застосувати обране кольорове рішення до індивідуального проекту.

При оформленні книг чи іншої друкованої продукції важливою проблемою є знаходження гармонійних кольорових сполучень. Якщо, наприклад оформити обкладинку в дві фарби, то залежно від вибраних кольорів їх сполучення сприйматиметься як гармонійне (“гарне") або як негармонійне (“негарне").

В пошуках гармонії колориту постає питання про вибір цілої гами (інколи досить широкої) не конфліктуючих один 3 одним кольорів, тобто вибір “палітри”, або загального колориту продукції. Відомо, наприклад, що ряд блідих кольорів може створювати приємне враження, але достатньо помістити між ними один насичений колір, щоб вони здались брудними, негарними. Насичений і яскравий колір, як правило, “вбиває” слабші та сіруваті. Цілий ряд умов може створювати враження більшої чи меншої привабливості кольору. Тому поєднання кольорів, які зазвичай розглядаються як кольорові гармонії, фактично визначаються естетикою ізольованого кольору, оскільки комбінація цих кольорів посилює враження чистоти кожного 3 них.

Основними критеріями у виявленні властивостей кольорів є визначення - світлий або темний. Без світлоти не буде поняття, що використовується для вираження ідей та емоцій кольору. Вторинні аспекти кольору стосуються комбінацій, які збалансовано існують одна 3 одною. Колір поєднує в собі індивідуальні та універсальні якості, варіанти його сприйняття нескінченні.

Існує 10 базових кольорових комбінацій.

Ахроматична - застосовуються білий, чорний та сірий кольори.

Аналогова - використовується будь-яка i3 послідовних гам, будь-які іiі тони та відтінки.

Контрастна - колір поєднується 3 гамою, що розташована праворуч або ліворуч від доповнення.
Доповнююча - використовуються діаметрально протилежні кольори спектра.

Монохроматична - використовується одна гама в комбінації 3 одним або всіма іiі тонами та відтінками.

Нейтральна - використовується гама, яка була приглушена або нейтралізована додаванням ії доповнюючого чорного кольору.

Роздільно доповнююча - створюється 3 однієї або двох гам по два боки їі доповнення.

Первинна - комбінуються чисті гами червоного, жовтого та голубого кольорів.

Вторинна - комбінуються вторинні зелений, фіолетовий та оранжевий кольори.

Третинна - тріадою служить одна 3 двох комбінацій: червоно-оранжева, жовтозелена та синьо-фіолетова або синьо-зелена, жовто-оранжева та червоно-фіолетова [9].

Деякі спеціалісти 3 кольору та кольорознавства колірні гармонії поділяють на дві групи: контрастні та нюансні. Контрастні гармонії грунтуються на протиставленні кольорів, що беруть участь у композиції за однією або декількома характеристиками (колірний тон, світлота, насиченість, площа). Найбільш контрастною за колірним тоном є гармонія взаємно доповнюючих кольорів. Поєднання доповнюючих (контрастних) кольорів здається різким, але ефектним, і часто використовується в рекламі або дизайні упаковки.

В основі нюансних гармоній лежать близькі за колірним колом кольори. Використання колірних тріад засновано на поєднанні трьох кольорів, які рівно відносяться на колірному колі. Важливим показником гармонії $\epsilon$ так званий домінуючий колір, який $є$ основним у композиції. В контрастних гармоніях решта кольорів протиставляються домінуючому, а в нюансних гармоніях вони, навпаки, наближаються до нього та підпорядковуються його основним рисам.

Колір також може якісно виграти, якщо буде розміщений на чорному фоні. Зазвичай поєднання світлого i темного кольорів не створює враження посилення чистоти обох. Дійсно, якщо темний контрастний колір посилює враження яскравості, а разом 3 тим $\mathrm{i}$ чистоти світлого, то сусідній світлий, навпаки, знижує яскравість темного. І лише у випадку, коли темним є чорний колір, контраст світлого на темному не має негативної (забруднюючої) дії. Уявне потемніння чорного кольору робить його ще глибшим, чорнішим, тобто чистішим. Таким чином, від поєднання 
світлого і темного виграють обидва кольори. Цей ефект дуже широко використовується в орнаментах.

Контрастні поєднання привабливі для друкованої продукції рекламно-плакатного типу; вони можуть використовуватись і при оформленні обкладинки, якщо вона має плакатний характер.

Поєднання додаткових кольорів створюватиме більш заспокійливе враження, якщо один 3 кольорів буде чистим, а інший - висвітленим чи затемненим. Можна використати також два затемнених або два висвітлених кольори (темно-червоний i темно-зелений, світло-червоний і світло-зелений), що створить більш спокійну гармонію. Крім тонів (3 додаванням білого) і відтінків (з додаванням чорного) кольорів можна варіювати і насиченістю, тобто утворювати кольори 3 додаванням сірого кольору різної світлоти.

Дисгармонія двох кольорів може бути пом'якшена зменшенням площі, яку займає один 3 них, а також шляхом внесення нейтралізуючих елементів (розділяючий чорний чи білий колір, сіре поле та ін.). Неприємне враження, яке створюють негармонійні фарби, можна також зменшити їх затемненням. Дуже часто дисгармонійні фарби дають зовсім інший ефект при багаторазовому ритмічному повторі.

Гармоніями між похідними одного кольору називають поєднання двох або кількох тонів чи відтінків одного i того ж кольору, наприклад поєднання чистого кольору і висвітленого або чистого і затемненого. Ці поєднання в більшості випадків створюють спокійне, приємне враження. Вони можуть доповнювати гармонії іншого виду. Так, наприклад, гармонію чотирьох кольорів можна побудувати наступним чином: використати два гармонійних кольори і додати до них ще два кольори тих же тонів або відтінків. У випадку трьох кольорів можна використати два гармонійних і додатково один 3 них висвітлений чи затемнений.

Звичайний прийом при оформленні друкування темною фарбою на папері того ж кольорового тону, але світлому - також побудований на гармонії між похідними. У виробництві палітурок цей принцип гармонії має місце при блінтовому тисненні, оскільки в результаті впливу штампа матеріал палітурки набуває більш темного відтінку.
Якщо змінити один 3 кольорів, які входять в гармонійну комбінацію, то інші кольори для збереження закономірності також мають бути змінені. Наприклад, якщо в тріаді червоний, жовтий, синій використати червоний пурпурового відтінку, то жовтий має бути помаранчевим, а синій - зеленуватим. Якщо взяти помаранчево-червоний, то жовтий доведеться взяти зеленуватим, а синій - 3 фіолетовим відтінком. Таким чином, кожного разу всі три кольори зсуватимуться в один і той же бік по колірному колу. До кожної пари або тріади можна, крім того, додавати білий колір, чорний і сірий, а також золото і срібло.

Узагальнюючи відомості про гармонію кольору і колірних композицій, можна зробити такі висновки: найкращі поєднання дають кольори у рамках більших та малих інтервалів у колірному колі, гірші - в рамках середніх інтервалів; малі інтервали сприймаються радше як відтінки одного й того ж кольору, а не як поєднання кольорів; при поєднанні кольорів слід дотримуватися співвідношення світлоти, яка має місце в колірному колі; більш інтенсивні кольори при поєднанні 3 менш інтенсивними слід використовувати в меншій кількості; хроматичні кольори можна співвідносити 3 ахроматичними, при чому теплі кольори виграють від поєднання 3 темними, а холодні - зі світлими.

Та попри все, закони кольорових гармоній досить відносні і ні в якому разі не можуть бути встановлені раз і назавжди. Вони переважно засновані на приватних спостереженнях, узагальнених до “загальних норм" [10]. Суб'єктивні колірні уподобання засвідчують неоднозначність уявлень про гармонійність та дисгармонійність колірних сполучень. Якщо розробник ставить перед собою завдання інтерпретації суб'єктивних колірних проявів, він не має задовольнятися лише оцінкою конкретних колірних характеристик чи їхньої виразності, адже головними чинниками тут є загальна тональність в цілому, взаємне розташування кожного кольору, їхній рух, яскравість, світлота чи затемненість, пропорційність, структура та колірний ритм. Не можна забувати також і про важливість максимального збереження об'єктивності попри індивідуальні колірні уподобання, і тут вкрай необхідне дисципліноване колористичне мислення та знання колірних можливостей оскільки саме це дозволяє уникнути типових 
помилок "особистого смаку" та однобічності в колористичному вирішенні проекту.

Необхідний підвищений професійний підхід до використання законів колористичної побудови гармонійно організованих композицій, що базуються на широкій палітрі відтінків, взаємозв'язку та виразності елементів колірної композиції, адже і в живопису, і в поліграфічному виробництві колір є основою художньої мови, потужним чинником для впливу на почуття та створення певного настрою.

Висновки. Питання сприйняття кольору та створення колірної гармонії є однією 3 важливих складових при розробці та художньому проектуванні об'єктів поліграфічного та мультимедійного виробництва. У цьому контексті вкрай важливим стає набуття сучасним поліграфістом знань 3 колірної відповідності зображення, загальної естетики і законів колірної гармонійності. Вивчення механізмів сприйняття кольору i досягнення колірної гармонії $є$ важливим моментом як у процесі набуття студентами теоретичних знань, так і практичного застосування комплексу закономірностей гармонійного кольороутворення під час пошуку рішення друкованої продукції, особливо за умов широкого використання можливостей комп'ютерної графіки.

Отже, враховуючи те, що підхід до кольору як константи естетичного сприйняття дуже актуальний при розробці об'єктів поліграфічного та мультимедійного виробництва, питання колірної гармонії в контексті проблематики художнього проектування і дизайну потребують подальших досліджень та більш глибокого вивчення.

Сучасній поліграфії України потрібен синтез у кольорографіці, тобто поєднання основних традиційних питань теорії кольору і теоpiї композиції, питань психофізіології сприйняття кольору 3 новітніми чинниками - використанням природної гармонійності кольорів, українських колористичних традицій, особливостей кольороутворення у прикладних графічних програмах та у цифрових технологіях сучасного поліграфічного виробництва.

\section{Список літератури}

1. Рунге В. Ф. Основы теории и методологии дизайна. М.: МЗ-Пресс, 2001. 252 с.

2. Прищенко С. В. Комп'ютерні технології у моделюванні колірних гармонійних сполучень. Технічна естетика і дизайн: зб. наук. пращь. К.: Віпол, 2006. Вип. 5-6.

3. Прищенко С. В. Естетичні параметри колористичного формоутворення в рекламній графіці України: автореф. дис... канд. техн. наук: 05.01.03. К.: КНУБА, 2008. $20 \mathrm{c}$.

4. Кузнєцова I. О. Моделювання візуального сприйняття об'єктів дизайну, декоративно-прикладного і образотворчого мистецтва: дис... д-ра техн. наук: 05.01.03. К.: КНУБА, 2006. $415 \mathrm{c}$.

5. Кафтанджиев $\mathrm{X}$. Гармония в рекламной коммуникации. М.: Эксмо, 2005. 368 с.

6. Олтман P. Corel Draw 9. Полное руководство. пер. с англ. М. Энтроп, 2000. 783 с.

7. О'Квин Д. Допечатная подготовка. Руководство дизайнера. М.: И. д.: Вильямс, 2001.590 c.

8. Харченко B.I. Проблеми колірної гармонії у контексті графічного дизайну. Україська академія мистеитва: зб. наук. праць. К.: НАОМА, 2013. Вип. 20.

9. Саттон Т. Гармония цвета: Полное руководство по созданию цветовых комбинаций / пер. с англ. М.: ООО «Издательство Астрель»: ООО «Издательство АСТ», 2004. $215 \mathrm{c}$.

10. Стефанов С., Тихонов В. Цвет в полиграфии и не только. М.: Репроцентр М, 2003. $320 \mathrm{c}$.

\section{References}

1. Runhe, V. F. (2001) Theory and Methodology Desighn Basis. M.: MZ-Press. 252 p. [in Russian].

2. Pryshchenko, S. V. (2006) Computer Technology for harmony color combinations modeling. Technical aesthetics and desighn: collection of scientific work. K.: Vipol. Issue 5-6 [in Ukrainian].

3. Pryshchenko S. V. (2008) Aesthetic parameters of colorforming in advertising graphics of Ukraine: abstract of the thesis of candidate of technical Sciences: 05.01.03. K.: KNUCA. 20 p. [in Ukrainian].

4. Kuznetzova I. O., Кузнєцова I. O. (2006) Modeling visual perception of design objects, applied arts and fine arts: thesis of candidate of technical Sciences: 05.01.03. K.: KNUCA. 415 p. [in Ukrainian]. 
5. Kaftandzyjev H. (2005) Advertising Communication Harmony. M.: Eksmo. 368 p. [in Russian].

6. Oltmann R. (2000) Corel Draw 9. Complete Guide. Translation from English. M.: Antrop. 783 p. [in Russian].

7. O’Quin D. (2001) Prepress. Designer's Guide. M.: Williams. 590 p. [in Russian].

8. Harchenko V. I. (2013) Problems of color harmony in the context of graphic design. Ukrainian Academy of Art: collection of scientific works. K.: National Academy of Architecture and Art. Issue 20. [in Ukrainian].

9. Satton T. (2004) Color Harmony Workbook: A Workbook and Guide to Creative Color Combinations. Translation from English. M.: OOO «Astrel Issue»: OOO «Issue AST» 215 p. [in Russian].

10. Stephanov S, Tihonov V. (2003) Color in Poligraphy and even more . M.: Reprocenter M. 320 p. [in Russian].

T. I. Veretil'nyk, Ph.D., associate professor

e-mail: vertim@mail.ua

L. D. Mysnyk, Ph.D., associate professor

e-mail: l.mysnyk@chdtu.edu.ua

O. W. Manzjura, senior lecturer e-mail: fktm-email@ukr.net

R. B. Kapitan, senior lecturer e-mail: kapitan_ruslan@ukr.net

Cherkassy State Technological University

460, Shevchenko avenue, Cherkassy, 18006, Ukraine

\section{USE OF COLOUR HARMONY AND REPRODUCTION IN POLYGRAPHY}

The item considers some aspects of color harmony and color formation in polygraphy, nature color harmony use in artistic design of objects of polygraphic and multimedia production.

Keywords: color, harmony, color combination, color harmony, color composition, color formation.

Стаття надійшла 14.05.2018.

Рецензенти: В. А. Ващенко, д.т.н., професор,

С. О. Воронов, д.т.н., професор. 